\title{
Malignant Thymoma
}

National Cancer Institute

\section{Source}

National Cancer Institute. Malignant Thymoma. NCI Thesaurus. Code C7612.

A thymoma that has an aggressive clinical course (capsular invasion, infiltration of the surrounding tissues) and can metastasize. Although any morphologic subtype of thymoma may eventually have a malignant clinical course, this term is most often associated with thymoma types B3 and C. 